\title{
Digitalisaatiolla luonnonvarat biotalouteen - luonnonvara-alan koulutuksentarjoajien yhteistoimintaa
}

\author{
Samu Palander ${ }^{1)}$, Ulla Moilanen ${ }^{2)}$, Paula Syri ${ }^{3)}$, Heli Wahlroos ${ }^{4)}$, Laura Vertainen ${ }^{5)}$, Anne-Mari \\ Väisänen ${ }^{6}$, Erkki Vasara ${ }^{7}$ \\ 1) Seinäjoen ammattikorkeakoulu,PL 412,60101 Seinäjoki,samu.palander@seamk.fi \\ ${ }^{2)}$ Hämeen ammattikorkeakoulu, PL 230,13101 Hämeenlinna, ulla.moilanen@hamk.fi \\ 3) Oulun ammattikorkeakoulu, PL 222,90101 Oulu, paula.syri@oamk.fi \\ 4) Savonia ammattikorkeakoulu, PL 6, 70201 Kuopio, heli.wahlroos@savonia.fi \\ 5) Jyväskylän ammattikorkeakoulu, PL 207,40101 Jyväskylä,laura.vertainen@jamk.fi \\ 6) Lapin ammattikorkeakoulu, Jokiväylä 11C, 96300 Rovaniemi, anne-mari.vaisanen@lapinamk.fi \\ 7)Luonnonvarakeskus, Latokartanonkaari 9,00790 Helsinki,erkki.vasara@luke.fi
}

\section{TIIVISTELMÄ}

Opetus, opiskelu ja sitä kautta oppiminen ovat muutoksessa. Digitaalisuus mahdollistaa opiskelun sitoutumatta aikaan ja paikkaan. Digitalisessa pedagogiikassa korostuvat oppijan ohjaus ja toimivat oppimistehtävät. Opetus- ja kulttuuriministeriön rahoittamassa luonnonvara-alan koulutusta antavien ammattikorkeakoulujen ja Luonnonvarakeskuksen yhteisessä Digitalisaatiolla luonnonvarat biotalouteen -hankkeessa (DLB-hanke) tuotetaan opetusmateriaalia kaikkien luonnonvara-alan opiskelijoiden käyttöön. Hankkeessa rakennetaan digitaalisia yhteistoteutuksia, pelillistetään oppimista, sujuvoitetaan opintopolkuja ja kehitetään ohjauksellisia toimintatapoja. Lisäksi järjestetään koulutuksen, työelämän ja tutkimuksen yhteistyöfoorumeja.

Hankkeessa on tuotettu verkko-oppimisympäristöön ammattikorkeakoulujen yhteisiä biotalousalan verkkokursseja. Pilotoidut verkkokurssit käsittelevät biotalouden vaihtoehtoja ja mahdollisuuksia sekä ajankohtaisia yksittäisiä teemoja, joista on laadittu jonkin tietyn ammattikorkeakoulun koordinoimia, mutta yhteisesti ristiinopiskelussa hyödynnettäviä kokonaisuuksia.

DLB-hankkeessa tutkitaan myös pelillisyyden hyödyntämistä luonnonvara-alan koulutuksessa. Hankkeessa on kehitetty biotalouspeli, joka toimii kokoavana oppimistehtävänä. Pelissä opiskelija tutustuu maa- ja metsätalouden kokonaisuuteen etenkin kierto- ja biotalouden näkökulmasta. Biotalouspeliä on tarkoitus hyödyntää myös nk. nivelvaiheopinnoissa toisen asteen opiskelijoille tavoitteena opintopolkujen sujuvoittaminen ja nopeuttaminen. Tätä tukee myös biotalouspeliin perustuva verkko-opintojakso.

Koulutuksen, työelämän ja tutkimuksen yhteistyöfoorumeissa on järjestetty alan tutkija-, kehittäjä- ja opiskelijatapaamisia. Näistä ns. tiedetreffeistä on tuotettu myös digitaalinen video sekä suoratoistona että tallenteena. Tiedetreffien otsikoina ovat olleet "Digitalisaation mahdollisuudet maaseutuyrityksen johtamisessa", "Ruokaturvallisuus", "Biotalouden sivuvirrat ja energiaratkaisut", hanketoimintaa monipuolisesti esitellyt "Reseptejä biotalouteen", "Metsävaroista modernia liiketoimintaa" sekä "Monipuolinen toimiva maankäyttö pohjoisessa Suomessa". Tiedetreffien osallistujapalaute oli kokonaisuudessaan positiivista, ja annista merkittävimmäksi nähtiin uusi tieto ja ajatukset (67\% vastauksista).

Asiasanat: ammattikorkeakoulut, pelillistäminen, tieteen popularisointi 


\section{Hankkeen tausta}

Opetus, opiskelu ja sitä kautta oppiminen ovat muutoksessa. Digitaalisuus mahdollistaa aikaan ja paikkaan sitoutumattoman opiskelun, mikä vastaa nykyisiin ja tuleviin elinikäisen oppimisen tarpeisiin. Digitaalisessa pedagogiikassa korostuvat ohjaus ja toimivat oppimistehtävät, sekä oppijan aktiivisuus ja autonomia.

Opetus- ja kulttuuriministeriö vastaa oppimisen ja opetuksen uusiin haasteisiin tukemalla opetuksen kehittämistä hankerahoituksella. Luonnonvara-alan koulutusta antavien ammattikorkeakoulujen ja Luonnonvarakeskuksen (Luke) yhteisessä Digitalisaatiolla luonnonvarat biotalouteen -hankkeessa (DLB-hanke) tuotettiin yhdessä opintokokonaisuuksia sekä opetusmateriaalia kaikkien luonnonvaraalan opiskelijoiden käyttöön. Hanke toteutettiin 2/2017-6/2020, ja sitä koordinoi Hämeen ammattikorkeakoulu. Muina toteuttajina hankkeessa olivat JAMK, Karelia amk, Lapin AMK, Luke, Novia, OAMK, Savonia, SeAMK, TAMK, Turku AMK ja XAMK.

\section{Hankkeen tavoitteet ja toimenpiteet}

DLB-hankkeessa tavoitteena oli digitalisoida ja rakentaa opintojaksojen yhteistoteutuksia ammattikorkeakoulujen kesken, pelillistää luonnonvara-alan oppimista ja sujuvoittaa opintopolkuja toiselta asteelta ammattikorkeakouluun ja edelleen yliopistoon (ks. kuva 1). Digitaalisiin yhteistoteutuksiin ja opintopolkujen sujuvoittamiseen liittyi myös ohjauksellisten toimintatapojen kehittäminen ja uusien verkko-opetusmenetelmien kokeileminen ja toimivien ratkaisujen käyttöön ottaminen. DLB toimi myös valtakunnallisen ristiinopiskelun kehittämishankkeen (Ristiinopiskelun kehittäminen [viitattu 28.12.2019]) pilottina. Lisäksi järjestettiin koulutuksen, työelämän ja tutkimuksen yhteistyöfoorumeja, Tiedetreffejä, joiden tarkoituksena oli saada aikaan sidosryhmien vuorovaikutusta ja keskustelua.

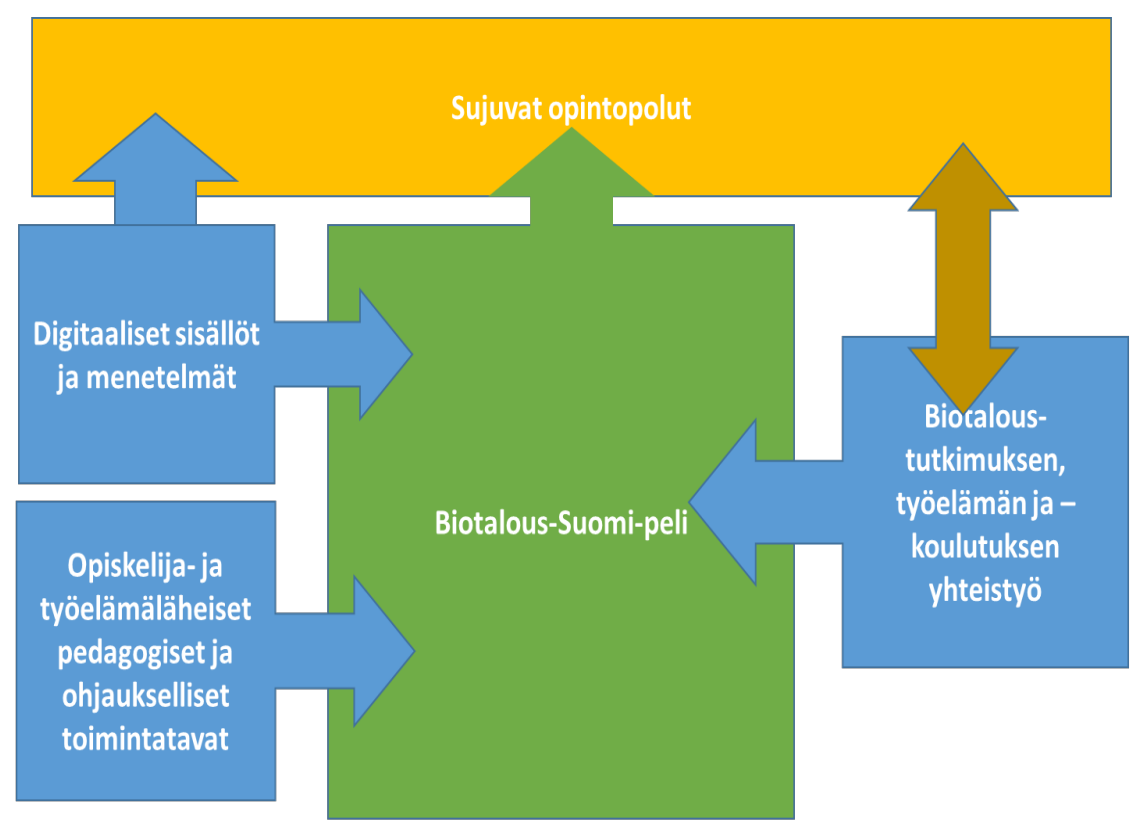

Koordinaatio

Kuva 1. Digitalisaatiolla luonnonvarat biotalouteen -hankkeen sisältö 


\section{Biotalouden verkko-opintotarjonta}

Hankkeessa suunniteltiin ja pilotoitiin eri ammattikorkeakoulujen yhteisiä biotalousalan verkkokursseja. Verkko-oppimisympäristössä päädyttiin käyttämään useissa ammattikorkeakouluissa käytössä olevaa Moodle-alustaa, joka on perustaltaan vapaasti hyödynnettävä avoimeen lähdekoodiin perustuva virtuaalinen oppimisympäristö (Moodle [viitattu 10.12.2019]). Verkkokurssit käsittelivät biotalouden vaihtoehtoja ja mahdollisuuksia sekä toisaalta ajankohtaisia yksittäisiä teemoja. Opintokokonaisuudet suunniteltiin teemojen mukaan kootuissa työryhmissä, ja yksittäisten opintojaksojen suunnittelu- ja toteutusvastuu jaettiin yhdelle tai useammalle ammattikorkeakoululle, joista yksi toimi vastuullisena koordinaattorina ja virallisena toteuttajakorkeakouluna. Näin sekä varmistettiin parhaan opettaja-asiantuntemuksen hyödyntäminen että huomioitiin ristiinopiskelun sujuvuus ja tarkoituksenmukaisuus. Taulukkoon 1 on koottu hankkeessa tuotettujen verkkoopintojaksojen tietoja.

Verkko-opintojen kehittäminen hankkeessa tukeutui Hiltusen (2012) esittämään vaiheittaiseen, sisältölähtöiseen suunnittelumalliin. Tämän mallin osa-alueet (tausta-analyysi, sisällönsuunnittelu, pedagoginen suunnittelu, tekninen suunnittelu, toteutus, testaus ja arviointi) toteutuivat DLB-hankkeen verkko-opintojen kehityksessä siten, että oppimisalustan tekninen suunnittelu johti hankkeessa käytettävään yhteiseen Moodle-pohjaan, ja opintojaksojen valmistuttua niitä testattiin ja vertaisarvioitiin hanketoimijoiden kesken eAMK:n laatukriteerien mukaan (eAMK 2017). Tausta-analyysi, sisällön suunnittelu sekä toteutuksen pilotointi puolestaan toteutettiin kussakin korkeakoulussa itsenäisesti tai opintokokonaisuudesta vastaavissa pienemmissä työryhmissä.

Verkko-opetuksen tukena toimi työpaketti, joka tähtäsi ohjauksellisten toimintatapojen kehittämiseen. Laadukkaassa verkko-opetuksessa ohjauksen merkitys korostuu (ks. esim. Anttila ym. 2011). Työpaketissa kehitettiin paitsi ohjaustapoja myös verkko-ohjaajien ohjaustaitoja. Työpaketissa hyödynnettiin myös muiden hankkeiden tuottamaa verkko-ohjausmateriaalia sekä eAMK- hankkeen webinaareja (ks. eAMK Menneet webinaarit [viitattu 29.12.2019]).

\section{Biotalouspeli}

DLB-hankeen keskeinen tavoite oli pelillisyyden hyödyntäminen luonnonvara-alan koulutuksessa. Tätä varten kehitettiin biotalouspeli, jonka tarkoitus on tutustuttaa oppija biotalouteen sekä toimia kokoavana oppimistehtävänä (Kuva 2). Pelinkehittämisen tavoitteena oli mallintaa virtuaalinen Suomi, joka toimii biotalouden voimin. Peliä pelaava opiskelija tutustuu maa-, metsä- ja puutarhatalouden sekä rakennetun ympäristön kokonaisuuteen biotalouden ja kiertotalouden näkökulmasta. Liiketaloudellinen näkökulma on kuitenkin tässä vaiheessa osittain rajattu pelistä pois, joten jatkokehitykselle on mahdollisuuksia.

Eri ammattikorkeakoulujen asiantuntijat vastasivat peliin maatalous-, metsätalous- ja puutarhatuotannon sekä rakennetun ympäristön syy-seuraussuhteita määrittelevän sisällön tuottamisesta ja peliä eteenpäin kuljettavien kysymysten laatimisesta. Varsinaista teknistä pelinkehitystä koordinoivat Lapin ammattikorkeakoulu ja sen FrostBit-ohjelmistotekniikan laboratorio. Biotalous voidaan nähdä kokonaissysteeminä, jolloin pelillistäminen tukee oppimista systeemidynamiikan ymmärtämisen kautta. Tällöin voidaan oppia hahmottamaan järjestelmän rakenteellisia vaikutussuhteita. Pelit ovat hyviä systeemidynamiikan oppimisvälineitä, koska niiden yksinkertaistetuissa systeemeissä järjestelmän sisäiset syy-seuraussuhteet ovat tavallista helpommin hahmotettavissa (ks. Harviainen ja Lainema 2012). 
Taulukko 1. DLB-hankkeessa tuotetut verkko-opintojaksot

\begin{tabular}{|c|c|c|}
\hline Verkko-opintojakso & Opintopisteet & Vastuutoteuttaja \\
\hline Biotalouden arvoverkot & 5 & HAMK \\
\hline Biotalouden mahdollisuudet & 15 & HAMK \\
\hline GIS in bioeconomy 1 \& 2 & $5+5$ & Novia \\
\hline Kasvien kasvu eri ympäristöissä & 5 & HAMK \\
\hline Luonnon monimuotoisuus & 5 & Lapin amk \\
\hline Siipikarjanlihan- ja munantuotanto & 5 & SeAMK \\
\hline Perunaosaaminen & 5 & OAMK \\
\hline Nautojen hyvinvointi & 5 & Savonia \\
\hline Nautojen hyvinvoinnin mittaaminen & 5 & Savonia \\
\hline Calf management and welfare & 5 & OAMK \\
\hline Genetiikan sovellukset luonnonvara-alalla & 5 & Savonia \\
\hline Sheep Farming and Biodiversity & 5 & OAMK \\
\hline \multicolumn{3}{|l|}{ Farm scale Utilization of Biobased By-products: } \\
\hline 1 Sources and Potentials of Different Biomass By-products & 4 & JAMK \\
\hline 2A Biogas Production in Farm Scale & 3 & Turku AMK \\
\hline 2B Farm Scale Energy Production from Solid Biofuels & 3 & JAMK \\
\hline 3A Production and Application of Biochar in Farm Scale & 3 & HAMK \\
\hline 3B Plant Nutrients from Biobased By-products & 3 & JAMK \\
\hline Proteiinituotannon vaihtoehdot: & $5-15$ & \\
\hline Ruokahyönteiset & 5 & HAMK \\
\hline Valkuaiskasvit & 5 & SeAMK \\
\hline Projektityö & 5 & HAMK \\
\hline Alternative Proteins: Production and Use of Edible Insects & 5 & HAMK \\
\hline Possibilities of Forest Energy & 5 & XAMK \\
\hline Metsikön kasvatuksen kannattavuus & 5 & Karelia \\
\hline Metsätilan kannattavuus & 5 & Karelia \\
\hline
\end{tabular}




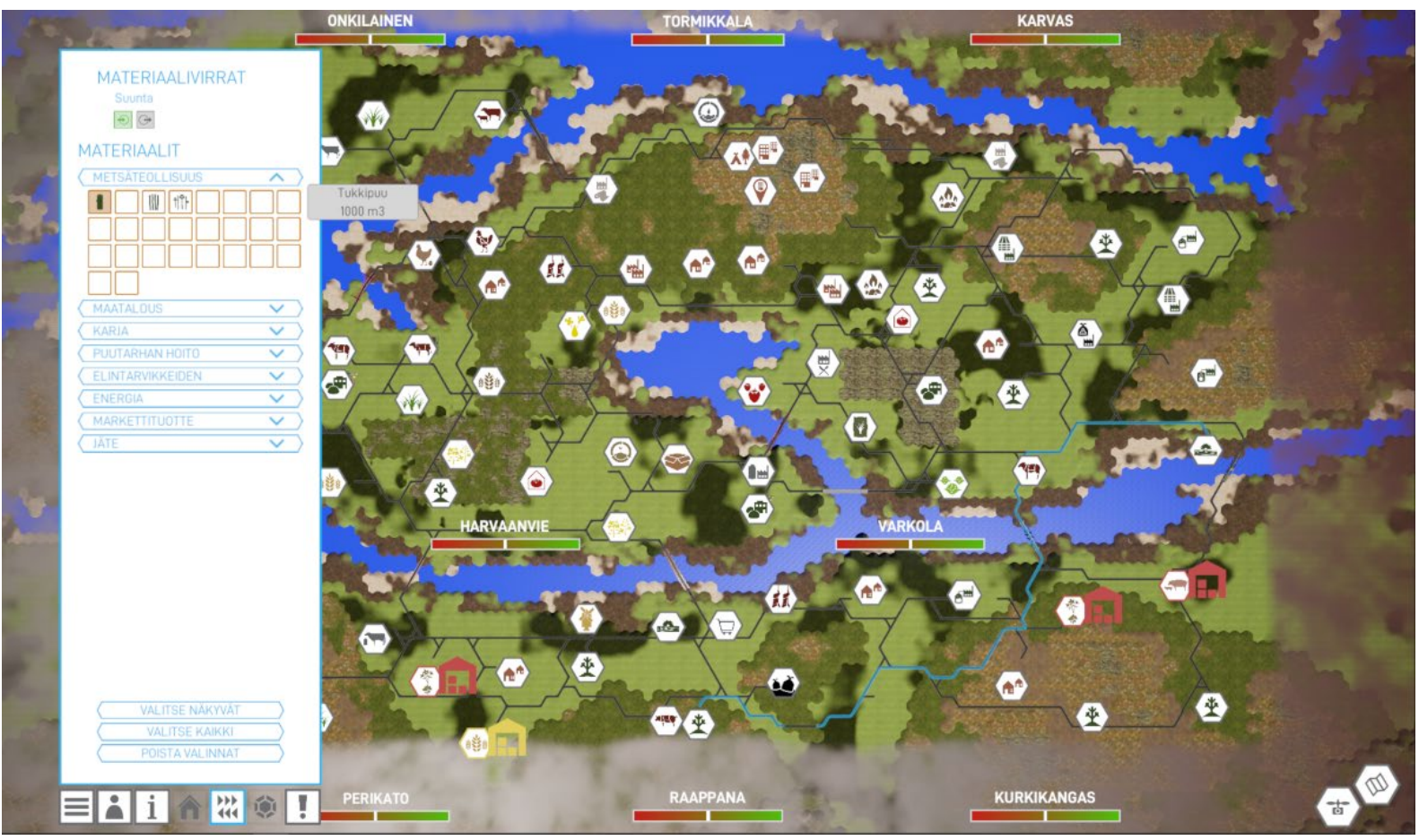

Kuva 2. Ote biotalouspelin karttanäkymästä

Biotalouspelin tavoitteena oli tuoda uusi pedagoginen lähestymistapa ja menetelmä biotalouden monimutkaiseen kokonaisuuteen hahmottamista tukemaan. Pelillistämisen tarkoituksena on myös tehdä biotaloudesta houkuttelevampaa ja helpommin lähestyttävämpää opiskelijan näkökulmasta.

\section{Digitalisoidut tiedetreffit}

Biotaloustutkimuksen, työelämän ja koulutuksen yhteistyö -teema pitää sisällään alan tutkija-, kehittäjäja opiskelijatapaamisia. Nämä ns. tiedetreffit toteutettiin sinänsä perinteisen kaavan mukaisina seminaaritilaisuuksina, joista tuotettiin myös digitaalinen video sekä suoratoistona että tallenteena. DLB-hankkeen tiedetreffisarjan kokoavina teemoina olivat digitaalisuus, luonnonvarat ja biotalous. Tilaisuuksien otsikoita olivat "Digitalisaation mahdollisuudet maaseutuyrityksen johtamisessa" (järjestäjä Oulun AMK), "Ruokaturvallisuus" (Seinäjoen AMK, Ilmajoki), "Biotalouden sivuvirrat ja energiaratkaisut" (Jyväskylän AMK), hanketoimintaa monipuolisesti esitellyt "Reseptejä biotalouteen" (Hämeen AMK), "Metsävaroista modernia liiketoimintaa" (Karelia AMK) sekä "Monipuolinen toimiva maankäyttö pohjoisessa Suomessa" (Lapin AMK).

\section{Case: Ruokaturvallisuus-tiedetreffit - kehittämishanketoiminnan ja ruokaturvallisuuden opetuksen luonnollista yhteistoimintaa}

Ammattikorkeakouluissa kehitetään ammattikorkeakoululain edellyttämää (ks. L 14.11.2014/932) TKIhanketoiminnan ja ammattikorkeakouluopetuksen integraatiota. DLB-hanke, joka lähtökohtaisestikin oli nimenomaan alan opetuksen kehittämiseen keskittyvä hanke, sisälsi luontaisen yhteyden opetukseen ja opiskeluun. Maatalousaiheisia DLB-hankkeen tiedetreffeistä olivat "Digitalisaation mahdollisuudet maaseutuyrityksen johtamisessa" ja "Ruokaturvallisuus".

Seinäjoen ammattikorkeakoulun ruokayksikön opetussuunnitelmassa on kaikille yksikön aloittaville opiskelijoille yhteisesti suunnattu opintojakso Ruokaketjun vastuullisuus (SeAMK 2017). Ilmajoen ruokaturvallisuus-tiedetreffeille osallistuminen kuuluikin opintojakson ohjelmaan, joten ammattilaisten 
lisäksi osallistujina oli Ilmajoella toistasataa tutkinto-opiskelijaa. Lisäksi muut hankkeeseen osallistuvat ammattikorkeakoulut tarjosivat opiskelijoille etäosallistumismahdollisuuden. Tilaisuudesta tuotettiin myös tallenne (SeAMK Live 2018a, b). Tallenne sisältää myös paljon lähdeviittauksia; esille tulleesta laajasta materiaalista on tässä artikkelissa referoitu vain osaa.

\section{Katsaus ruokaturvallisuuden ajankohtaisiin aiheisiin}

Ennen varsinaista tieteellistä osuutta seminaarissa kuultiin viranomaisnäkökulma sekä alkutuotannon ja elintarviketeollisuuden puheenvuoro katsauksena ruokaturvallisuuden ajankohtaisiin aiheisiin. Vielä 2017 Elintarviketurvallisuusviraston nimellä toiminut Ruokavirasto toteuttaa Suomessa viranomaisorganisaationa $\mathrm{mm}$. elintarvikkeiden turvallisuuden ja laadun valvontaa. Suomalaista elintarviketurvallisuuttahan on yleisesti pidetty hyvänä, ja valvontaviranomaisen selvitykset tukevat tätä (Evira 2017). Samaan johtopäätökseen päästään kansainvälisessä vertailussa (ks. esim. EFSA 2017).

\section{Ruokahävikki ja siihen vaikuttaminen}

Maailmassa haaskaantuvan ruoan määrästä on tehty kansainvälistäkin arviointia, ja voidaan olettaa, että noin kolmannes tuotetusta ruoasta ei päädy syötäväksi (FAO 2011). Alustuksessa esitettiin Luken sekajätetutkimuksessa määritetyksi suomalaisen tuottaman ruokajätteen määräksi n. $25 \mathrm{~kg}$ vuodessa (Silvennoinen \& Korhonen 2013). Aiheesta on uutisoitu ja keskusteltu useissa alan ammattijulkaisuissa ja mm. Maaseudun Tulevaisuudessa (ks. esim. Silvennoinen ym. 2012, Silvennoinen 2013). Tiedetreffit toivat tämän aiheen nyt tulevaisuuden ruokaketjun ammattilaisten pohdittavaksi, ja se herätti vilkasta keskustelua esimerkiksi kotitalouksien ruokahävikkiin vaikuttavan asukkaan sukupuolen osalta.

\section{Ravitsemuksen ja ruokaturvallisuuden yhteys}

Tämä aihe sisälsi sekä elintarvikkeiden koostumukseen ja ravintosisältöön että prosessointiin ja sen vaikutuksiin liittyviä huomioita. Esityksen alkuosa keskittyi maitoon ja sen merkitykseen ns. anabolisena elintarvikkeena (ks. esim. Melnik 2015). Kuluttajat ovat viime vuosina usein osoittaneet kiinnostusta raakamaidon positiivisiin terveysvaikutuksiin, mutta asian taustat ja toisaalta myös pitävä tieteellinen näyttö ovat jääneet osin avoimiksi, ja esim. Claeysin ym. (2013) tutkimusten mukaan kuumennuksen vaikutus maidon ravintoarvoon vaikuttaa vähäiseltä. Suomessa maito on pastöroitu lakisääteisesti 1950-luvulta alkaen. Maidon pastöroinnin lisäksi myös muut elintarvikkeiden kuumennuskäsittelyt ovat olleet kiinnostuksen kohteena. Näillä voisi olla alustuksen mukaan vaikutusta myös ihmisen suolistomikrobifloorassa ajan mittaan tapahtuneisiin tai tapahtuviin muutoksiin.

\section{Tiedetreffien palautteesta poimittua}

Tiedetreffien osallistujapalaute oli jokseenkin kokonaisuudessaan positiivista, ja arvosanaksi esitettiin hyvää, erinomaista tai kiitettävää. Tätä voi pitää erinomaisena tuloksena, etenkin kun otetaan huomioon, että esim. Ilmajoen tilaisuuteen osallistui huomattava joukko opiskelijoita vieläpä Seinäjoelta saapuneina. Annista merkittävimmäksi on nähty uusi tieto ja ajatukset (67 \% vastauksista).

Vapaamuotoisessa palautteessa kiitettiin sisältöä ja monipuolisuutta. Opiskelijan näkökulmasta vastaava tilaisuus, jossa ruokaketjun kokonaisuutta valtakunnantason asiantuntijoiden toimesta lähestytään, ei helposti opintojen aikana toistu. Tulevissa ruokaketjun vastuullisuuden opinnoissa ja opetuksessa voidaan hyödyntää tilaisuuden digitaalista tallennetta, vaikkakaan se ei täysin vastaa osallistumista itse elävään tilaisuuteen ja keskusteluun. 


\section{Johtopäätökset}

DLB-hankkeen tavoitteena oli koota kymmenen luonnonvara-alan ammattikorkeakoulua kehittämään sekä pilotoimaan alan koulutusta koordinoidusti ja uusia digitaalisia menetelmiä hyödyntäen. Hankkeen tuloksena syntyi 17 uutta verkko-opintojaksoa (yht. 126 op), biotalouspeli sekä alan asiantuntijoiden ja sidosryhmien kohtaamisfoorumi, Tiedetreffit. Hankkeen myötä syntyi uusia kontakteja alan opettajien kesken, ja yhteistyö opetuksen sekä ristiinopiskelun kehittämisen parissa syveni ja monimuotoistui. Yhteistyö, parhaiden käytänteiden jakaminen sekä kokemusten vaihtaminen nähtiin avaintekijöiksi vastaamaan alan kehityksen sekä oppimisen murroksen tuottamiin haasteisiin.

\section{Kirjallisuus}

Anttila, E.-H., Juvonen, P. \& Parikka, H.-K. 2011. Verkko-opetuksen hyvät käytänteet. Saimaan ammattikorkeakoulun julkaisuja Sarja A: Raportteja ja tutkimuksia 14. $33 \mathrm{~s}$. https://www.theseus.fi/bitstream/handle/10024/25729/verkko-opetuksen.pdf?sequence=1

Claeys, W., Cardoen, S., Daube, G. De Block, J., Dewettinck, K., Dierick, K., De Zutterde, L., Huyghebaert A., Imberechts, H., Thiange, Vandenplas, Y. \& Herman, L. 2013. Raw or heated cow milk consumption: Review of risks and benefits. Food Control 31: 251-262. https://doi.org/10.1016/j.foodcont.2012.09.035

EFSA 2017. The European Union summary report on trends and sources of zoonoses, zoonotic agents and foodborne outbreaks in 2016. EFSA Journal 15:5077. 228 s. https://doi.org/10.2903/j.efsa.2017.5077

eAMK 2017. Verkkototeutusten laatukriteerit. Saatavana: https://www.eamk.fi/globalassets/tutkimus-ja-kehitys-research-and-development/tki-projektien-lohkot-ja-tiedostot/eamk/teema1/laatukriteerit/eamk_laatukriteerit_valmis.pdf

eAMK. Menneet webinaarit. Viitattu 29.12.2019. https://www.eamk.fi/fi/projekti/menneet-webinaarit/

Evira 2017. Raportti Suomen elintarvikeketjun monivuotisen kansallisen valvontasuunnitelman $2014-2018$ toteutumisesta vuonna 2016. Eviran raportti 290/0411/2017.

FAO 2011. Global food losses and food waste - extent, causes and prevention. Rooma: Food and Agriculture Organization of the United Nations. http://www.fao.org/docrep/014/mb060e/mb060e00.pdf

Harviainen, J. T. \& Lainema, T. 2013. Pelit, systeemidynamiikka ja oppiminen. Teoksessa: Suominen, J. ym. (toim.): Pelitutkimuksen vuosikirja 2013. Tampereen yliopisto.

Hiltunen, L. 2012. Verkko-opetuksen suunnittelun tehostaminen. Tietojenkäsittelytiede 34: 37-53.

Hämeen ammattikorkeakoulu. Hankkeen kuvaus ja tavoitteet. Viitattu 28.5.2018.

http://www.hamk.fi/tyoelamalle/hankkeet/dlb/Sivut/hankkeen-kuvaus-ja-tavoitteet.aspx

Melnik, B. 2015. Milk: an epigenetic amplifier of FTO-mediated transcription? Implications for Western diseases. Journal of Transitional Medicine 13:385. https://doi.org/10.1186/s12967-015-0746-z

Moodle. Viitattu 21.12.2019. https://docs.moodle.org/38/en/About_Moodle

L 14.11.2014/932. Ammattikorkeakoululaki.

Ristiinopiskelun kehittäminen. Viitattu 28.12.2020.

https://wiki.eduuni.fi/pages/viewpage.action?pageId=29753817

SeAMK 2017. Opinto-opas 2017-2018. Agrologi (AMK). https://opintoopas.seamk.fi/index.php/fi/21/fi/71/AGRO17/year/2017

SeAMK Live 2018a. 7.2.2017 Tiedetreffit Ruokaketjujen elintarviketurvallisuus 1/2. [videotallenne]. Viitattu 23.5.2018. https://www.youtube.com/watch? $\mathrm{v}=$ MIyApFylgc0\&feature=youtu.be

SeAMK Live 2018b. 7.2.2017 Tiedetreffit Ruokaketjujen elintarviketurvallisuus 2/2. [videotallenne]. Viitattu 23.5.2018. https://www.youtube.com/watch?v=FpJzJ4A3V1w\&feature=youtu.be

Silvennoinen, K. 2013. Pääkaupunkiseudun asukas heittää roskiin 24 kiloa ruokaa vuodessa.

Maaseudun Tiede 3. 
Silvennoinen, K. \& Korhonen, O. 2013. Food waste volume and composition in Helsinki region households. In: Perspectives on managing life cycles: Proceedings of the 6th international conference on life cycle management, Gothenburg.

Silvennoinen, K., Jalkanen, L., Katajajuuri, J.-M., Koivupuro, H.-K. \& Reinikainen, A. 2012. Ruokahävikki suomalaisessa ruokaketjussa. Elintarvike ja terveys 26: 18-23. 